\title{
Macrophyte Bioassay Applications for Monitoring Pesticides in THE AQUATIC ENVIRONMENT ${ }^{1}$
}

\author{
Utilização de Bionsaios com Macrófitas no Biomonitoramento de Agrotóxicos em Ambiente \\ Aquático
}

DELLA VECHIA, J.F. ${ }^{2}$, CRUZ, C..$^{2,3}$, SILVA, A.F. ${ }^{3}$, CERVEIRA JR., W.R. ${ }^{3}$, and GARLICH, N. ${ }^{3}$

\begin{abstract}
The objective of this study was to evaluate the feasibility of the use of macrophytes Lemna minor and Azolla caroliniana as biomarkers of exposure (acute toxicity) for atrazine, bentazon + imazamox and clomazone, insecticide alpha cypermethrin + teflubenzuron and fungicides pyraclostrobin and mixture pyraclostrobin + epoxiconazole, as well as the risk for environmental intoxication. For this purpose, four plants of $L$. minor and five of A. caroliniana were selected in a $50 \mathrm{~mL}$ Hoagland medium. For both plants, the following concentrations were used: 0.10; 1.07; 3.44; 11.16; 36.40 and $118.0 \mathrm{mg} \mathrm{L}^{-1}$ of each test product and a control with three replicates. The results of this study demonstrated higher sensitivity of L. minor to the tested pesticides, when compared to A. caroliniana. L. minor can be used in the monitoring of herbicides bentazon, atrazine and clomazone and pyraclostrobin-based fungicide, and A. caroliniana can be used for pyraclostrobinbased fungicides, due to the sensitivity of these organisms when exposed.
\end{abstract}

Keywords: bioindication, aquatic plants, acute toxicity, environmental monitoring, pesticide.

\begin{abstract}
RESUMO - O objetivo deste estudo foi avaliar a viabilidade na utilização das macrófitas Lemna minor e Azolla caroliniana como bioindicadores de exposição (toxicidade aguda) dos herbicidas atrazina, bentazon + imazamox e clomazone, do inseticida alfacipermetrina + teflubenzuron e dos fungicidas piraclostrobina e mistura piraclostrobina + epoxiconazol, bem como o risco de intoxicação ambiental. Para isso, foram selecionadas quatro plantas de L. minor e cinco de A. caroliniana em $50 \mathrm{~mL}$ de meio de cultivo Hoagland. Em ambas as plantas foram utilizadas as concentrações de $0,10,1,07,3,44,11,16,36,40$ e $118,0 \mathrm{mg} \mathrm{L}^{-1}$ de cada produto testado e um controle, com três réplicas. Os resultados obtidos neste estudo demonstraram maior sensibilidade da planta $\mathbf{L}$. minor, comparada a A. caroliniana, aos agrotóxicos testados. L. minor pode ser empregada no monitoramento de herbicidas à base de bentazon, atrazina e clomazone e do fungicida à base de piraclostrobina, e A. caroliniana, do fungicida à base de piraclostrobina, devido à sensibilidade desses organismos quando expostos.
\end{abstract}

Palavras-chave: bioindicação, plantas aquáticas, toxicidade aguda, monitoramento ambiental, agrotóxico.

\section{INTRODUCTION}

The use of pesticides is an important factor to maintain the high agricultural productivity; however, the intensification and inadequate use of these products may contribute for the pollution of the earth (Jennings and Li, 2014) and waters (Santos et al., 2015). Among the herbicides, a atrazine (photosystem II inhibitor) has caused some environmental issues (Santos et al., 2015) due to its diversified use to control pre- and post-emergence weeds; bentazon + imazamox (inhibitor of photosystem II and the acetolactate synthase enzyme) is used to control mono and eudicotyledons during the post-emergence state (Ferhatoglu et al., 2005); and clomazone (carotenoid synthesis inhibitor), which is used

Recebido para publicação em 23.1.2016 e aprovado em 19.3.2016.

2 Centro Universitário da Fundação Educacional de Barretos, Barretos-SP, Brasil, < jaque_dellavechia@hotmail.com>; ${ }^{3}$ Universidade Estadual Paulista "Júlio de Mesquita Filho" Jaboticabal-SP, Brasil. 
to promote the loss of virtually all plant pigments (albinism) (Bessegato et al., 2012).

The mixture of the pesticides alphacypermethrin + teflubenzuron (pyrethroid and benzoylurea) has been emphasized due to the fact that they are used in several cultures (Pinto Junior et al., 2011), as well as the use of fungicides pyraclostrobin and the mixture pyraclostrobin+epoxiconazole (chemical group of strobilurin and triazole), which have a systemic action and are used for cotton, peanuts, oat, banana, potato, coffee, corn, soy and wheat (Prestes et al., 2013).

These products used for farming may reach the water bodies due to drifting, surface runoff and leaching (Geoffroy et al., 2004), promoting changes to the several environmental compartments (Prestes et al., 2013). Some organisms may be used as biological indicators for the presence of contaminants on the environment (Costa et al., 2008). In order to create a base for these evaluations, organisms that represent the several levels of the food chain are used on acute and chronic toxicity assays. These studies are easy-to-use tools and they offer results on the possible ecotoxicological effects of pesticides on nontarget organisms on the water environments (Florêncio et al., 2014).

Lemna minor is a standardized macrophyte for toxicity assays (OECD, 2002) and it has been used on studies with pesticides 2.4-D (Belgers et al., 2007), diquat and fomesafen (Gorzerino et al., 2009), atrazine, isoproturon and alachlor (Coutris et al., 2011), glyphosate (Kielak et al., 2011), and imazapyr (Cruz et al., 2015). Another macrophyte that may be used as a bioindicator is Azolla caroliniana, due to its easy management, short cycle of life, short height and since it is a cosmopolitan species; however, it still requires studies on its sensitivity as a bioindicator. This macrophyte has been used for the evaluation of pesticides glyphosate, clomazone, oxyfluorfen and 2.4-D (Silva et al., 2012), in addition to imazapyr (Cruz et al., 2015).

With the intensification of farming and the large-scale use of pesticides, it is necessary to increase the monitoring of the possible environmental effects. Therefore, the objective of this study was to evaluate the feasibility of using $L$. minor and A. caroliniana as bioindicators of exposure (acute toxicity) for the herbicides atrazine, clomazone and bentazon + imazamox, the alpha-cypermetrin + teflubenzuron insecticide and fungicides pyraclostrobin and mixture of pyraclostrobin + epoxiconazole, as well as the risk of environmental intoxication.

\section{MATERIAL AND METHODS}

The herbicides tested were atrazine (CAS: 1912-24-9) with active ingredient concentration of $500 \mathrm{~g} \mathrm{~L}^{-1}$ on the Atrazine Nortox $^{\circledR}$-Nortox S/A formulation; bentazon (25057-89-0) + imazamox (114311-32-9) with $600+28 \mathrm{~g} \mathrm{~L}^{-1}$ on the Amplo ${ }^{\circledR}$-Basf S/A formulation; clomazone (81777-81-1) with $360 \mathrm{~g} \mathrm{~L}^{-1}$ on the Gamit ${ }^{\mathbb{B}}-\mathrm{FMC}$ Corporation formulation; insecticide alpha-cypermetrin (67375-30-8) + teflubenzuron (83121-18-0) with $75+75 \mathrm{~g} \mathrm{~L}^{-1}$ on the Imunit ${ }^{\circledR}$-Basf S/A formulation; and fungicides pyraclostrobin (175013-18-0) with $250 \mathrm{~g} \mathrm{~L}^{-1}$ on the Comet ${ }^{\mathbb{B}}$ Basf S/A formulation, and the mixture pyraclostrobin +epoxiconazole (106325-08-0) com $260+160 \mathrm{~g} \mathrm{~L}^{-1}$ on the Abacus ${ }^{\circledR}$-Basf S/A formulation.

Macrophytes $L$. minor and A. caroliniana were cultivated on a plastic box with volume for 2.5 liters, containing water and substrate constituted by soil, sand and organic matter $\left(2: 1: 1 ; \mathrm{vv}^{-1}\right)$, on a greenhouse. The acclimatization of the macrophytes was conducted on a bioassay room, with temperature at $25.0 \pm 2.0{ }^{\circ} \mathrm{C}$, photoperiod of 12 hours and lighting of 1,000 lux, for three days. After the acclimatization, the plants were disinfected with an aqueous sodium hypochlorite $2 \%$ solution for L. minor and 3\% for A. caroliniana.

Then, four L. minor plants were selected, with three fronds each, as well as five A. caroliniana plants, placed on glass containers with capacity for $100 \mathrm{~mL}$, containing $50 \mathrm{~mL}$ of Hoagland culture medium, for 24 hours; then, other $50 \mathrm{~mL}$ of Hogland with the pesticides were added, at $\mathrm{pH} 5.86$, for 24 hours, for acclimatization.

In order to evaluate the sensitivity of the plant batches, before the acute toxicity assays, assays were conducted with the reference 
substance sodium chlorite $(\mathrm{NaCl}-P . A)(\mathrm{OECD}$, 2002). The CL50;7d (lethal concentration of $50 \%$, for 7 days) of $\mathrm{NaCl}$ for $L$. minor was of $0.65 \mathrm{~g} \mathrm{~L}^{-1}$, with a confidence interval of $95 \%$ between 0.69 and $0.62 \mathrm{~g} \mathrm{~L}^{-1}$; and for A. caroliniana, of $2.14 \mathrm{~g} \mathrm{~L}^{-1}$, with interval between 2.31 and $1.97 \mathrm{~g} \mathrm{~L}^{-1}$.

After determining the sensitivity, the definite assays for acute toxicity on a static system were conducted. For such, $50 \mathrm{~mL}$ of Hoagland were added to each test container, with the herbicides, insecticide and fungicides. For both plants, the following concentrations were used: $0.10,1.07,3.44,11.16,36.40$ and $118.0 \mathrm{mg} \mathrm{L}^{-1}$ of each product and one control, with three repetitions per concentration. The evaluation of the mortality percentage of the plants was conducted three, five and seven days after exposure.

For L. minor, the mortality and percentage of chlorosis and necrosis of the fronds was evaluated, as recommended by OECD (2002). For A. caroliniana, the mortality used was according to the grade scale (E and A) (SILVA et al., 2012). The mortality results were subjected to linear regression, and the lethal concentration of 50\% (CL50;7d) was estimated by the Trimmed Spermam Karber software (Hamilton et al., 1977).

With the lethal concentration values of $50 \%$, pesticides were classified according to the environmental hazard potential suggested by IBAMA (2016). The environmental intoxication risk of the pesticides was determined and classified using the risk quotient (RQ) method, according to Goktepe et al. (2004). On this method, the risk is calculated by dividing CAE (estimated environmental concentration) by CL50;7d obtained on the acute toxicity assays. In order to determine CAE, the highest recommended doses for application in the field for each pesticide were used, and the uniform distribution of the chemical products on the body of water was considered, over an area of 1.0 ha $\left(10,000 \mathrm{~m}^{2}\right)$.

\section{RESULTS AND DISCUSSION}

\section{Ecotoxicity for L. minor}

For L. minor, the lethal concentration of $50 \%$ (CL50;7d) of atrazine was $5.27 \mathrm{mg} \mathrm{L}^{-1}$, with lower limit (LI) of $4.39 \mathrm{mg} \mathrm{L}^{-1}$ and upper limit (LS) of $6.33 \mathrm{mg} \mathrm{L}^{-1}$. The CL50;7d of bentazon + imazamox was $31.58 \mathrm{mg} \mathrm{L}^{-1}$, with LI of $23.99 \mathrm{mg} \mathrm{L}^{-1}$ and LS of $41.56 \mathrm{mg} \mathrm{L}^{-1}$, and for clomazone, $10.23 \mathrm{mg} \mathrm{L}^{-1}$, with LI of $7.91 \mathrm{mg} \mathrm{L}^{-1}$ and LS of $13.23 \mathrm{mg} \mathrm{L}^{-1}$.

L. minor was less sensitive to these herbicides than to flumioxazin, with CL50;48h of $3.6 \mu \mathrm{g} \mathrm{L}^{-1}$ (Geoffroy et al., 2004); to metsulfuron (CL50;7d of $12.0 \mathrm{\mu g} \mathrm{L}^{-1}$ ), to triasulfuron $\left(0.24 \mu \mathrm{g} \mathrm{L}^{-1}\right)$; to MCPA (5765 $\left.\mu \mathrm{g} \mathrm{L}^{-1}\right)$; to terbuthylazine $\left(200 \mu \mathrm{g} \mathrm{L}^{-1}\right)$; to diquat $\left(60 \mu \mathrm{g} \mathrm{L}^{-1}\right)$; and to aciflourfen $\left(506 \mu \mathrm{g} \mathrm{L}^{-1}\right)$ (Cedergreen et al., 2007); to the atrazine, isoproturon and alachlor mixture $(50+35+15 \%)$, with CL50;96h of $70.0 \mu \mathrm{g} \mathrm{L}^{-1}$ (Coutris et al., 2011); and than imazapyr, with CL50;7d of $1.06 \mathrm{mg} \mathrm{L}^{-1}$ (Cruz et al., 2015); however, it was more sensitive to glyphosate (CL50 of $19.6 \mathrm{mg} \mathrm{L}^{-1}$ ) and to mecoprop, with $12.2 \mathrm{mg} \mathrm{L}^{-1}$ (Cedergreen et al., 2007).

For atrazine on control, at 0.10 and $1.07 \mathrm{mg} \mathrm{L}^{-1}$, there was no mortality. At $3.44 \mathrm{mg} \mathrm{L}^{-1}$ mortality occurred on $61.6 \%$ of fronds; at $11.16 \mathrm{mg} \mathrm{L}^{-1}$, on $66 \%$; at $36.40 \mathrm{mg} \mathrm{L}^{-1}$, on $85.0 \%$; and at $118.0 \mathrm{mg} \mathrm{L}^{-1}$, on $100 \%$, with the linear equation and concentrationmortality correlation shown on Table 1. For clomazone on control and at $0.10 \mathrm{mg} \mathrm{L}^{-1}$, there was no mortality; at $3,44 \mathrm{mg} \mathrm{L}^{-1}$, it corresponded to $36 \%$; at $11.16 \mathrm{mg} \mathrm{L}^{-1}$, to $30 \%$; at $36.40 \mathrm{mg} \mathrm{L}^{-1}$, to $30 \%$; at $118.0 \mathrm{mg} \mathrm{L}^{-1}$, to $100 \%$, with linear equation (Table 1 ).

This herbicide did not show an adequate correlation as to the concentration-mortality relationship, with $\mathrm{R}^{2}=0.54$ (Table 1), indicating that some type of degradation of the herbicide may have occurred; however, the degradation of clomazone due to the sunlight on aqueous solutions has not been reported in the literature (Tenbrook and Tjeerdema, 2006).

For bentazon + imazamox, on control, at $0.10 \mathrm{mg} \mathrm{L}^{-1}$ and at $1.07 \mathrm{mg} \mathrm{L}^{-1}$, there was no mortality. At $3.44 \mathrm{mg} \mathrm{L}^{-1}$, the mortality corresponded to $10 \%$ of the fronds; at $11.16 \mathrm{mg} \mathrm{L}^{-1}$, it corresponded to $25 \%$; at $36.40 \mathrm{mg} \mathrm{L}^{-1}$, to $56.25 \%$; and at $118.0 \mathrm{mg} \mathrm{L}^{-1}$, to $72 \%$, with the linear equation and concentration-mortality correlation shown on Table 1. 
Table 1 - Representation of linear equations and correlation $\left(\mathrm{R}^{2}\right)$ of the concentration-mortality relationship for the tested products

\begin{tabular}{|l|c|c|}
\hline \multicolumn{1}{|c|}{ Lemna minor } & Linear equation & $\mathrm{R}^{2}$ \\
\hline Atrazine & $\mathrm{y}=21.711 \mathrm{x}-23.973$ & 0.90 \\
\hline Clomazone & $\mathrm{y}=13 \mathrm{x}-5.666$ & 0.54 \\
\hline Bentazon + imazamox & $\mathrm{y}=15.964 \mathrm{x}-28.167$ & 0.90 \\
\hline Alpha-cypermethrin + Teflubenzuron & $\mathrm{y}=1.576 \mathrm{x}+12.125$ & 0.42 \\
\hline Pyraclostrobin + Epoxiconazole & $\mathrm{y}=5.103 \mathrm{x}-5.995$ & 0.65 \\
\hline Pyraclostrobin & $\mathrm{y}=14.57 \mathrm{x}+10.667$ & 0.96 \\
\hline Azolla caroliniana & Linear equation & $\mathrm{R}^{2}$ \\
\hline Atrazine & $\mathrm{y}=10.511 \mathrm{x}-2.673$ & 0.89 \\
\hline Clomazone & $\mathrm{y}=6.857 \mathrm{x}-1.800$ & 0.54 \\
\hline Bentazon + imazamox & $\mathrm{y}=6.631 \mathrm{x}-0.126$ & 0.61 \\
\hline Alpha-cypermethrin + Teflubenzuron & $\mathrm{y}=0.158 \mathrm{x}-0.370$ & 0.42 \\
\hline Pyraclostrobin + Epoxiconazole & $\mathrm{y}=6.4294 \mathrm{x}-12.960$ & 0.65 \\
\hline Pyraclostrobin & $\mathrm{y}=18.549 \mathrm{x}-8.653$ & 0.96 \\
\hline
\end{tabular}

For the alpha-cypermetrin + teflubenzuron mixture at CL50;7d > $100.0 \mathrm{mg} \mathrm{L}^{-1}$ with the concentration-mortality correlation of only 0.42 for L. minor (Table 1), similar to teflubenzuron also for this bioindicator, with CL50;7d > $1,000.0 \mathrm{mg} \mathrm{L}^{-1}$ (Medeiros et al., 2013). The mortality of L. minor exposed to the associated insecticides alpha-cypermetrin + teflubenzuron varied from $17.76 \%$ at $0.10 \mathrm{mg} \mathrm{L}^{-1}$ to $23.87 \%$ at $36.40 \mathrm{mg} \mathrm{L}^{-1}$. For the pyraclostrobin fungicide at CL50;7d, it reached $1.82 \mathrm{mg} \mathrm{L}^{-1}$, with $\mathrm{LI}$ of $1.18 \mathrm{mg} \mathrm{L}^{-1}$ and LS of $2.82 \mathrm{mg} \mathrm{L}^{-1}$; and for the pyraclostrobin + epoxiconazole mixture at CL50;7d > $100.0 \mathrm{mg} \mathrm{L}^{-1}$, with the concentration-mortality relationship shown on Table 1 .

According to Prestes et al. (2011), the pyraclostrobin + epoxiconazole mixture showed CL50;72h of $0.20 \mathrm{mg} \mathrm{L}^{-1}$ for the Pseudokirchneriella. Subcapitata alga, while pyraclostrobin alone showed CL50;72 of $5.57 \mathrm{mg} \mathrm{L}^{-1}$, and epoxiconazole, of $1.14 \mathrm{mg} \mathrm{L}^{-1}$; therefore, these authors mention that the magnification factor of the toxicity corresponded to 13.6 times in relation to the individual toxicity of each compound; however, this effect was not characterized for toxicity on L. minor.

OECD (2009) determines the maximal concentration (limit for acute toxicity assay) of $100.0 \mathrm{mg} \mathrm{L}^{-1}$, since the lack of mortality at this concentration indicates that the organism does not belong to the most sensitive group to the substance at short-term exposures. Based on this rule, it is not possible to use $L$. minor for the biomonitoring of alpha-cypermetrin + teflubenzuron and pyraclostrobin + epoxiconazole, since no sensitive response occurs (correlation between concentration and mortality) for these products (Table 1).

\section{Ecotoxicity for $A$. caroliniana}

For A. caroliniana, the lethal concentration (CL50;7d) of atrazine, clomazone and bentazon+imazamox and of the alphacypermetrin + teflubenzuron insecticide was higher than $100.0 \mathrm{mg} \mathrm{L}^{-1}$, similarly to $2.4-\mathrm{D}$ (708.35 $\left.\mathrm{mg} \mathrm{L}^{-1}\right)$ and to clomazone (129.63 $\left.\mathrm{mg} \mathrm{L}^{-1}\right)$ (Silva et al., 2012), which shows the low sensitivity of this bioindicator; the correlation between concentration and mortality is shown on Table 1. Azolla filiculoide exposed to the mixture of herbicides atrazine, isoproturon and alachlor $(50+35+15 \%)$ showed CE50;21d of $60.0 \mathrm{\mu g} \mathrm{L}^{-1}$ (Coutris et al., 2011), and for Azolla pinnata exposed at 0.001 and $0.002 \mathrm{mg} \mathrm{L}^{-1}$ of carbofuran (Furadan ${ }^{\mathbb{Q}}$ ), there was no inhibition of the NPK fixation by the plant (El-Shahate et al., 2011), considering that they are much more sensitive than A. caroliniana.

For atrazine, bentazon+imazamox and clomazone on control and at $0.10 \mathrm{mg} \mathrm{L}^{-1}$, there was no mortality of plants during the 
experimental period. Between 1.07 and $118.0 \mathrm{mg} \mathrm{L}^{-1}$, mortality reached 23.3 and $66.6 \%$, respectively. For the alpha-cypermetrin + teflubenzuron insecticide and for the pyraclostrobin + epoxiconazole fungicide, the mortality of A. caroliniana occurred only at 36.4 and $118.0 \mathrm{mg} \mathrm{L}^{-1}$. For pyraclostrobin, on control at $0.10 \mathrm{mg} \mathrm{L}^{-1}$, no mortality occurred. At $1.07 \mathrm{mg} \mathrm{L}^{-1}, 36.6 \%$ of mortality occurred; at $3.44 \mathrm{mg} \mathrm{L}^{-1}, 51.0 \%$ occurred; at $11.16 \mathrm{mg} \mathrm{L}^{-1}$, $70 \%$; at $36.40 \mathrm{mg} \mathrm{L}^{-1}, 80 \%$; and at $118.0 \mathrm{mg} \mathrm{L}^{-1}$, $100 \%$ of mortality occurred with the concentration-mortality correlation shown on Table 1.

For Silva et al. (2012), glyphosate (Scout ${ }^{\mathbb{B}}$ and Trop ${ }^{\circledR}$ ) showed CL50;7d of $23.66 \mathrm{mg} \mathrm{L}^{-1}$ and $38.91 \mathrm{mg} \mathrm{L}^{-1}$, respectively; oxyfluorfen, of $80.50 \mathrm{mg} \mathrm{L}^{-1}$; and imazapyr, of $18.98 \mathrm{mg} \mathrm{L}^{-1}$ (Cruz et al., 2015), which indicates a higher sensitivity of A. caroliniana to these herbicides than to the ones tested on this study using the same plant (A. caroliniana).

The CL50;7d of pyraclostrobin for A. caroliniana was of $3.22 \mathrm{mg} \mathrm{L}^{-1}$, with LI of $2.36 \mathrm{mg} \mathrm{L}^{-1}$ and LS of $4.40 \mathrm{mg} \mathrm{L}^{-1}$; for the pyraclostrobin + epoxiconazole mixture, CL50;7d > $100.0 \mathrm{mg} \mathrm{L}^{-1}$. These values were similar to the evaluation made by Probst et al. (2005) with epoxiconazole (CL50;72h of $1.66 \mathrm{mg} \mathrm{L}^{-1}$ ) and by Ochoa-Acuña et al. (2009) with pyraclostrobin $\left(1.4 \mathrm{mg} \mathrm{L}^{-1}\right)$; however, they differed from the ones obtained by Coors and Frische (2011) with pyraclostrobin exposed to the alga (CE50 of $0.15 \mathrm{mg} \mathrm{L}^{-1}$ ).

The mixture of the pyraclostrobin + epoxiconazole fungicides evaluated by Prestes et al. (2011) with the alga $P$. subcapitata promoted different effects than the ones found by this study, with growth promotion at the lowest concentrations $\left(0.01 \mathrm{ad} 0.10 \mathrm{mg} \mathrm{L}^{-1}\right)$ up to 48 hours of exposure, followed by growth inhibition at the other doses $(0.01,0.10,1.0$, 10.0 and $100.0 \mathrm{mg} \mathrm{L}^{-1}$ ), and for the products alone (pyraclostrobin and epoxiconazole), there was a promotion on the growth of algae.

\section{Comparative analysis across bioindicators, ecotoxicological classification and environmental intoxication risk}

According to the CL50;7d data obtained, L. minor was sensitive to the herbicides atrazine, bentazon+imazamox and clomazone, and to the fungicide pyraclostrobin, while A. caroliniana was sensitive to the fungicide pyraclostrobin. The order of CL50;7d for $L$. minor was pyraclostrobin $>$ atrazine $>$ clomazone $>$ bentazon+imazamox > alpha-cypermetrin + teflubenzuron $=$ pyraclostrobin + epoxiconazole and, for $A$. caroliniana, pyraclostrobin $>$ atrazine $=$ clomazone $=$ bentazon+imazamox $=$ alphacypermetrin + teflubenzuron $=$ pyraclostrobin + epoxiconazole.

Atrazine and pyraclostrobin were classified as very toxic, and clomazone and bentazon + imazamox, as moderately toxic, for L. minor (IBAMA, 2016). The other tested products were considered slightly toxic. L. minor was more sensitive to the herbicide metsulfuron-methyl in comparison to Elodea canadensis, Callitriche platycarpa, Potamogeton crispus, Ceratophyllum demersum, C. submersum, Batrachium trichophyllum, Berula erecta, Sparganium emersum, Spirodela polyrrhiza and L. trisulca (Cedergreen et al., 2004), which indicates its potential to be used for the biomonitoring of pesticides, specially herbicides, on water environments. According to Fairchild et al. (1997), this plant is sensitive to triazines, such as atrazine, sulphonylureas (metsulfuron and clorsulfuron), pyridines (diquat and paraquat), dinitroaniline (trifluralin) and acetanilide (alachlor and metolachlor).

The herbicides atrazine, clomazone and bentazon+imazamox, insecticide alphacypermetrin + teflubenzuron, and fungicide pyraclostrobin + epoxiconazole were classified as slightly toxic, and the fungicide pyraclostrobin, as very toxic, for $A$. caroliniana (IBAMA, 2016). A. caroliniana was sensitive to pyraclostrobin, which indicates the possibility of using it for the biomonitoring of this fungicide e group.

The insecticide alpha-cypermetrin + teflubenzuron and fungicide pyraclostrobin + epoxiconazole were the molecules that shoed the lowest toxicity for the tested bioindicators, which may be due to the fact that the insecticide is an inhibitor for chitin (benzoylureas) and the central nervous system (pyrethroids) and that the association of fungicides promotes an antagonist effect of 
Table 2 - Risk quotient values (RQ) for the tested products

\begin{tabular}{|c|c|c|}
\hline Pesticides & Lemna minor & Azolla caroliniana \\
\hline Atrazine & 0.0759 & 0.0040 \\
\hline Clomazone & 0.0148 & 0.0015 \\
\hline Bentazon + imazamox & 0.0049 & 0.0015 \\
\hline Alpha-cypermethrin + Teflubenzuron & 0.00007 & 0.00007 \\
\hline Pyraclostrobin + Epoxiconazole & 0.0002 & 0.0002 \\
\hline Pyraclostrobin & 0.0109 & 0.0062 \\
\hline
\end{tabular}

toxicity (Savoy, 2011). Cypermetrin, according to Wendt-Rasch et al. (2003), promoted a change on the composition of species, increasing the phytoplankton population on concentrations higher than $0.13 \mu \mathrm{g} \mathrm{L}^{-1}$. Fungicides pyraclostrobin + epoxiconazole promote high toxicity for the microcrustaceans Daphnia similis and the fish species tambaqui (Colossoma macropomum), both in combination and in isolation (Prestes et al., 2012 , 2013). The herbicide atrazine is the one that is most detected on surface and underground waters (Mudhoo and Garg, 2011; Santos et al., 2015), and bentazon has been identified on underground waters on the states of Virginia, Missouri, California and, more recently, in Florida (Bessegato et al., 2012).

On the environmental intoxication risk evaluation, according to Goktepe et al. (2004), atrazine is classified as a moderate environmental risk herbicide $(0.05<\mathrm{RQ}<0.5)$, and the other tested products are classified as low risk $(\mathrm{RQ}<0.05)$, for L. minor (Table 2). For A. caroliniana, all tested products were classified as low environmental risk $(R Q<0.05)$ (Table 2), even if $100 \%$ of the highest recommended dose for application in the field gets to the water environment.

The results obtained on this study showed a higher sensitivity of the L. minor plant, in comparison to A.caroliniana, to the tested pesticides. It shows low environmental intoxication risk for macrophytes. Therefore, it is concluded that L. minor may be used to monitor bentazon, atrazine and clomazonebased herbicides and the pyraclostrobinbased fungicide, and A. caroliniana may be used to monitor the pyraclostrobin-based fungicide.

\section{ACKNOWLEDGEMENTS}

This paper was financed by the São Paulo Research Foundation, Proc. 2013/10462-1, as a scientific research grant for the first author.

\section{REFERENCES}

Belgers J.D.M. et al. Effects of the herbicide 2,4-D on the growth of the nine aquatic macrophytes, Aquatic Bot. 2007;86:260-8.

Bessegato G.G. et al. Degradação fotoeletroquímica do herbicida bentazona sobre eletrodos de carbono modificados por tio ${ }_{2}$. Quím. Nova. 2012;35:332-6.

Cedergreen N. et al. Combination effects of herbicides on plants and algae: do species and test systems matter. Pest Manage Sci. 2007;63:282-95.

Cedergreen N. et al. Sensitivity of aquatic plants to the herbicide metsulfuron - methyl. Ecotoxicol Environ Safety. 2004;57:153-61.

Coors A, Frische T. Predicting the aquatic toxicity of commercial pesticides mixtures. Environ Sci Europe. 23; 22:1-18.

Costa C.R. et al. A toxicidade em ambientes aquáticos: discussão e métodos de avaliação. Quim. Nova. 2008;31:1820-30.

Coutris C. et al. Can we predict community-wide effects of herbicides from toxicity tests on macrophyte species?

Aquatic Toxicol. 2011;101:40-56.

Cruz C. et al. Imazapyr herbicide efficacy on floating macrophytes control and ecotoxicology for non-target organisms. Planta Daninha. 2015;33:103-8.

El-Shahate R.M. et al. Evaluation of the effect of three different pesticides on Azolla pinnata growth and NPKuptake. J Am Sci. 2011;7:1020-31. 
Fairchild J.F. et al. Comparative Sensitivity of Selenastrum capricornutum and Lemna minor to Sixteen Herbicides. Arch Environ Contam Toxicol. 1997;32:353-7.

Ferhatoglu Y. et al. The basic for safening of clomazone by phorate insecticide in cotton and inhibitors of cytochrome P450s. Pestic Biochemic Physiol. 2005;81:59-70.

Florêncio T. et al. Bioindicadores neotropicais de ecotoxicidade e risco ambiental de fármacos de interesse para aquicultura. B Instituto Pesca. 2014;40:569-76.

Geoffroy L. et al. Comparison of different physiological parameter responsesin Lemna minor and Scenedesmus obliquus exposedto herbicide flumioxazi Environ Poll. 2004;131:233-41.

Goktepe I. et al. Ecological risk assessment of Neem-based pesticides. J Environ Sci Health Part B. 2004;39:311-20.

Gorzerino C. et al. Effects of diquat and fomesafen applied alone and in combination with a nonylphenol polyethoxylate adjuvant on Lemna minor in aquatic indoor microcosms.

Ecotoxicol Environ Safety. 2009;72:802-10.

Hamilton M.A. et al. Trimmed Spearman-Karber method for estimating median lethal concentrations in toxicity bioassays. Environ Sci Technol. 1977;11:714-9.

Instituto Brasileiro do Meio Ambiente - IBAMA. Sistema de Classificação quanto ao Potencial de Periculosidade Ambiental - PPA, 2016. Acesso em: 15 mar. 2016.

Disponível em: http://www.ibama.gobr/qualidade-ambiental/ classificação_ppa.

Jennings A.A., Li Z. Scope of the worldwide effort to regulate pesticide contamination insurface soils. J Environ Manage. 2014;46:420-43.

Kielak E. et al. Phytotoxicity of Roundup Ultra 360 SL in aquatic ecosystems: Biochemical evaluation with duckweed (Lemna minor L.) as a model plant. Pestic Biochem Physiol. 2011;99:237-43.

Medeiros L.S. et al. Acute toxicity and environmental risk of teflubenzuron to Daphnia magna, Poecilia reticulata and Lemna minor in the absence and presence of sediment.

J Environ Sci Health B. 2013;48:600-6.

Mudhoo A., Garg K. Sorption, transport and transformation of atrazine in soils, minerals and composts: a review.

Pedosphere. 2011;21:11-25.
Ochoa-Acuña H.G. et al. Toxicity of soybean rust fungicides to freshwater algae and Daphnia magna. Ecotoxicology. 2009;18:440-6.

Organization for Economic Co-Operation and Development OECD. Guidelines for the testing of chemicals, Lemna $\mathbf{s}$ Growth inhibition test. Paris: 2002. 22p

Organization for Economic Co-Operation And Development - OECD. Guideline for testing of chemicals draft revised guideline. Fish, Acute Toxicity Test. Paris: 2009.

Pinto Junior A.R. et al. Control of Pseudoplusia includens (Walker, 1857) in the soybean culture with different insecticides. J Biotechnol Biod. 2011;2:16-20.

Prestes E.B. et al. Avaliação da toxicidade de piraclostrobin, epoxiconazol e sua mistura em alga Pseudokirchneriella subcapitata. Pestic R Ecotoxicol Meio Amb. 2011;21:39-46.

Prestes E.B. et al. Avaliação da toxicidade de piraclostrobin, epoxiconazol e sua mistura em Daphnia similis. Pestic R Ecotoxicol Meio Amb. 2012;22:43-50.

Prestes E.B. et al. Epoxiconazol e suas misturas em Colossoma macropomum (Tambaqui). Ecotoxicol Environ Contam. 2013;8:125-8.

Probst M. et al. Scenario-based simulation of runoff-related pesticide entries into small streams on a landscape level. Ecotoxicol Environ Safety. 2005;62:145-59.

Santos E.A. et al. Atrazine levels in the Jaboticabal water stream (São PauloState, Brazil) and its toxicological effects on the pacu fishPiaractus mesopotamicus. Arh Hig Rada Toksikol. 2015;66:73-82.

Savoy L.T. Classificação dos agrotóxicos. Biológico. 2011;73:91-2.

Silva A.F. et al. Ecotoxicidade de herbicidas para a macrófita aquática (Azolla caroliniana). Planta Daninha. 2012;30:5416.

Tenbrook L., Tjeerdema R.S. Biotransformation of clomazone in rice (Oryza sativa) and earlywatergrass (Echinochloa oryzoides). Pestic Biochem Physiol. 2006;85:38-45.

Wendt-Rasch L. et al. Effects of the pyrethroid insecticide cypermethrin on a freshwater community studied under field conditions. II. Direct and indirect effects on the species composito Aquatic Toxicol. 2003;63:373-89. 